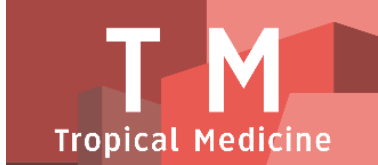

PAPER - OPEN ACCESS

\title{
Kandungan Total Flavonoid Dari Ekstrak Metanol Akar Imperata cylindrical (L) Beauv. (Alang-alang)
}
Author
DOI
: Diah Dhianawaty
Electronic ISSN
: 10.32734/tm.v1i3.256
Print ISSN
: $2623-0542$
: 2623-0550

Volume 1 Issue 3 - 2018 TALENTA Conference Series: Tropical Medicine (TM)

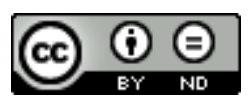

This work is licensed under a Creative Commons Attribution-NoDerivatives 4.0 International License.

Published under licence by TALENTA Publisher, Universitas Sumatera Utara
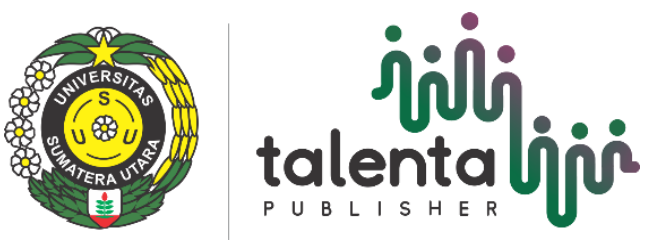


\title{
inili talenta
}

Available online at https://talentaconfseries.usu.ac.id

\section{Kandungan Total Flavonoid Dari Ekstrak Metanol Akar Imperata cylindrical (L) Beauv. (Alang-alang)}

\author{
Diah Dhianawaty ${ }^{a^{*},}$ Ruslin ${ }^{\mathrm{b}}$, Mas Rizky Anggun Adipurna Syamsunarno ${ }^{\mathrm{c}}$, \\ Helmi Hamimah $^{\mathrm{d}}$ \\ ${ }^{a c d}$ Departemen Ilmu Kedokteran Dasar, Divisi Biokimia dan Biomolekular, Fakultas Kedokteran,Universitas Padjadjaran Bandung 45363 \\ ${ }^{b}$ Departemen Kimia Medisinal, Fakultas Farmasi, Universities Halu Oleo, Kendari 93132 \\ dhianawaty@unpad.ac.id
}

\begin{abstract}
Abstrak
Masyarakat di Sulawesi Tenggara telah memanfaatkan akar alang-alang (Imperata cylindrica) sebagai obat hipertensi. Ekstrak methanol akar alang-alang dari Kendari terbukti mempunyai aktivitas antihipertensi. Studi menunjukkan senyawa-senyawa fenolat dapat menurunkan tekanan darah. Aktivitas penurunan tekanan darah dikarenakan senyawa-senyawa fenolat mempunyai aktivitas antioksidan dan kemampuan menghambat angiotensin converting enzyme (ACE). Berdasarkan penelitian yang dilaporkan, tujuan penelitian ini menentukan adanya flavonoid, dan mengukur kandungan flavonoid total dengan menggunakan metode aluminium klorida. Hasil analisis menunjukkan bahwa ekstrak mengandung flavonoid, dengan kandungan total flavonoid 1,17\%. Berdasarkan hasil diatas, dapat disimpulkan bahwa ekstrak mengandung flavonoid, and kadar total flavonoid 1,17\%.
\end{abstract}

Kata kunci: Imperata cylindrica, Alang-alang, kandungan total flavonoid

\begin{abstract}
The People in Southeast Sulawesi have been using the roots of alang-alang (Imperata cylindrica) as a hypertension drug. The methanol extract of alang-alang root from Kendari has been prove to have antihypertensive activity. Studies showed the phenolic compounds can decrease blood pressure. Blood pressure reduction activity is due to phenolic compounds have antioxidant activity and the ability to inhibit angiotensin converting enzyme (ACE). Based on the reported studies, the aim of this study was to determine the presence of flavonoids, and to measure the total flavonoid content by using aluminium chloride method. The results showed that the extract contained flavonoids, with a total flavonoid content of $1.17 \%$. Based on the above results, it can be concluded that, the extract contained flavonoid, and a total flavonoid content of $1.17 \%$.
\end{abstract}

Keywords: Imperata cylindrica, Alang-alang, total flavonoid content

\section{Pendahuluan}

Hipertensi adalah penyakit tidak menular yang merupakan beban bagi pemerintah Indonesia disamping beban penyakit menular. Jumlah penderita hipertensi hasil pengukuran di Sulawesi Tenggara 22,5\%, menempati urutan ke 23 dari 33 Provinsi di Indonesia. Prevalensi hipertensi di Provinsi Sulawesi Tenggara pada tahun 2013 mengalami kenaikan di banding tahun 2007. Diperoleh data selain berobat ke fasilitas kesehatan milik pemerintah, sebanyak 30,4\% masyarakat masih memanfaatkan Pelayanan Kesehatan Tradisional (Yankestrad), dan sebanyak 49,0\% memanfaatkan ramuan. Di Sulawesi Tenggara dari 15\% masyarakat yang memanfaatkan Yankestrad, sebanyak 32,8\% memanfaatkan ramuan [1]. 
Hipertensi diformulasikan dapat disebabkan antara lain oleh stres oksidatif dan meningkatnya aktivitas sistem renin angiotensin aldosterone (RAAS). Sel endotel memainkan peran utama dalam relaksasi arteri. Oksida nitrat dilepaskan oleh endotelium dan menyebabkan relaksasi vaskuler.Oksida nitrat cepat terdegradasi oleh anion superoksida, dimana anion superoksida bertindak sebagai vasokonstriktor, oleh sebab itu superoksida dapat menyebabkan disfungsi endotel, kontraktilitas yang berubah dan remodeling vaskuler. Hipertensi pada manusia dikaitkan dengan penurunan bioavailabilitas NO dan peningkatan stres oksidatif, oleh karena itu senyawa antioksidan dapat berperan dalam menurunkan stress oksidatif $[2,3]$.

Senyawa fitokimia mempunyai beberapa manfaat, diantaranya yaitu sebagai senyawa antioksidan. Flavonoid termasuk senyawa yang mempunyai aktivitas antioksidan yang termasuk ke dalam golongan molekul nonenzimatik, yang terlibat menonaktifkan ROS dari tingkat sel [4].

Adanya ikatan rangkap antara C2 dan C3 pada cincin C dalam struktur flavonoid mempengaruhi sifat antioksidan flavonoid. Kelompok karbonil pada posisi C4 memungkinkan senyawa untuk menginaktivasi radikal hidroksil.Kehadiran gugus $\mathrm{OH}$ pada posisi $\mathrm{C} 3$ pada cincin $\mathrm{C}$ memungkinkan senyawa tersebut menghambat peroksidasi lipid.Kemampuan untuk menginaktivasi radikal hidroksil meningkat dengan jumlah gugus hidroksil yang ada di cincin B, terutama pada posisi 3 'dan 4'.Kehadiran gugus hidroksil pada posisi C5 dan C7 pada cincin A, C3 'dan C4' pada cincin B, dan juga C3 pada cincin C meningkatkan penghambatan peroksidasi lipid $[5,6]$.

Angiotensin converting enzyme (ACE) adalah komponen kunci dalam RAAS, yang mengatur tekanan darah. Ekspresi berlebihan RAAS dikaitkan dengan hipertensi vaskuler, karena itu penghambatan ACE menjadi target utama pengendalian hipertensi $[7,8]$.

Efek menginhibisi ACE dianggap berasal dari adanya molekul flavonoid, yang membentuk kompleks khelat di pusat aktif ACE.Dari hasil docking, inhibisi ACE oleh flavonoid bergantung kepada struktur flavonoid. Fitur struktural utama aktivitas penghambatan ACE adalah: ikatan rangkap antara $\mathrm{C} 2$ dan $\mathrm{C} 3$ pada cincin $\mathrm{C}$; kelompok katekol di cincin B (3',4'-dihidroksi); dan kelompok ceton pada karbon C4 pada cincin-C [8].

Secara tradisional alang-alang telah dimanfaatkan untuk mengobati beberapa penyakit, seperti di Sulawesi Tenggara dimanfaatkan untuk hipertensi. Mengandung antara lain senyawa fenolat, flavonoid, Ruslin, dkk, membuktikan khasiat anti hipertensi ekstrak metanolnya terhadap tikus jantan galur Wistar $[9,10]$, demikian juga aktivitas antioksidannya telah diketahui $\mathrm{IC}_{50}=0,32 \mathrm{mg} / \mathrm{mL}[11]$.

\section{Bahan dan Metode}

Desain penelitian adalah studi eksperimental. Waktu penelitian dari bulan Januari sampai Februari 2018. Tempat penelitian laboratorium Biokimia dan Biologi molekuler FK Unpad kampus Jatinangor. Bahan yang diteliti adalah ekstrak metanol akar Imperata cylindrica, yang ditanam di Kendari (Sulawesi Tenggara). Pereaksi $\mathrm{AlCl}_{3}$ dan kalium asetat dari E.Merck dan kuersetin dari Sigma Aldrich. Alat untuk mengukur spektrofotometer Eppendorf Biospectrometer Basic AG 22331 Hamburg seri: 6135 BJ.

\subsection{Skrining flavonoid}

Dilakukan menurut metode BJ. Harbone [12]. 1 gram ekstrak ditambah $\mathrm{HCl}$ 2M, dipanaskan selama 30 - 40 menit, kemudian disaring. Filtrat yang diperoleh didinginkan, selanjutnya diekstraksi dengan etil asetat. Etil asetat diuapkan dan kemudian ditambahkan sedikit amil alkohol. Biarkan memisah, lapisan amil alkohol menjadi berwarna, hal ini menunjukkan adanya flavonoid.

\subsection{Penentuan total flavonoid.}

Dibuat kurva baku kuersetin dengan konsentrasi 6, 8, 10, 12, dan 14 bpj (bagian perjuta). Dari kurva baku diperoleh persamaan regresi linier yang digunakan untuk menghitung kesetaraan kuersetin.

Ekstrak yang diteliti ditimbang $90 \mathrm{mg}$, dan dilarutkan dalam metanol sampai volume larutan mencapai $25 \mathrm{ml}$. Diambil $100 \mu \mathrm{l}$ sampel lalu ditambah $900 \mu \mathrm{l}$ metanol, kemudian ditambahkan $1 \mathrm{ml} \mathrm{AlCl}_{3} 2 \%$ dan $1 \mathrm{ml}$ kalium asetat $120 \mathrm{mM}$. Campuran diinkubasi pada suhu kamar selama 1 jam. Selanjutnya, serapan diukur pada P anj ang gelombang $435 \mathrm{~nm}[13,14]$. 
Kadar total flavonoid ekstrak dihitung dengan rumus sbb:

$\mathrm{F}=\frac{\mathrm{C} \times \mathrm{V} \times \mathrm{F} \times 100 \%}{\mathrm{~m}}$

dimana:

$\mathrm{F}=$ Jumlah flavonoid dengan metode alumunium klorida, $\mathrm{C}=$ Kesetaraan kuersetin $(\mathrm{g} / \mathrm{ml})$,

$\mathrm{V}=$ Volume total ekstrak etanol $(\mathrm{ml}), \mathrm{F}=$ Faktor pengenceran, $\mathrm{m}=$ Berat sampel $(\mathrm{g})$

\section{Hasil Dan Pembahasan}

\subsection{Skrining flavonoid.}

Dari perlakuan terhadap ekstrak metanol akar alang-alang seperti prosedur skrining di atas diperoleh perubahan warna dari amil alkohol, Perubahan ini menandakan adanya kandungan flavonoid di dalam ekstrak. Dengan demikian terbukti ekstrak metanol akar alang-alang mengandung flavonoid.

\subsection{Penentuan total flavonoid.}

Kurva baku kuersetin

Tabel 1. Serapan Standar Kuersetin dalam Konsentrasi 6, 8,10, 12, 14 bpj

\begin{tabular}{lll}
\hline No & Konsentrasi kuersetin (bpj) & Serapan \\
\hline 1 & 6 & 0,157 \\
2 & 8 & 0,203 \\
3 & 10 & 0,267 \\
4 & 12 & 0,294 \\
5 & 14 & 0,361 \\
\hline
\end{tabular}

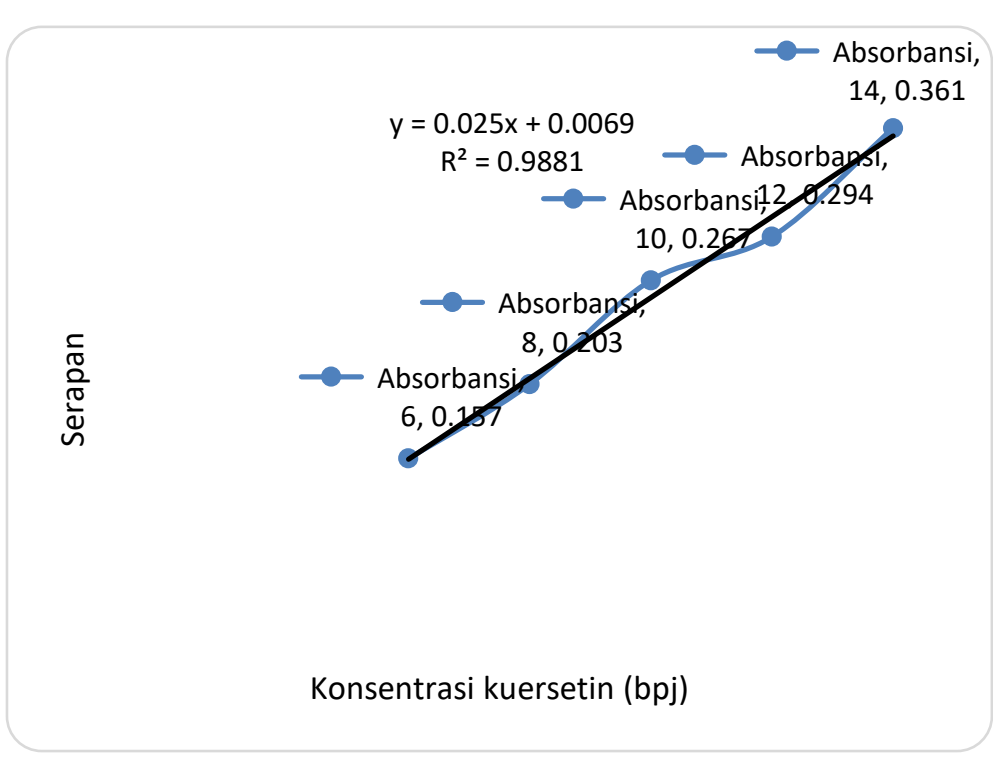

Gambar 1. Kurva Standar Kuersetin

Dari kurva baku kuersetin diperoleh persamaan regresi liner yaitu $y=0,025 x+0,0069$.

Dimana nilai $\mathrm{x}=0,0042 \mathrm{mg} / \mathrm{ml}$ adalah kesetaraan kuersetin. 
Kadar total flavonoid ekstrak terukur $=\mathrm{F}=\frac{\mathrm{C} \times \mathrm{V} \times \mathrm{F} \times 100}{\mathrm{~m}}=1,17 \%$

Diperoleh kadar total flavonoid dalam ekstrak $=1,17 \%$.

Berdasarkan analisis yang telah dilakukan ekstrak metanol akar alang-alang dari Kendari mengandung flavonoid, dan kandungan total flavonoidnya $1,17 \%$.

Hipertensi dapat disebabkan antara lain oleh stres oksidatif dan meningkatnya aktivitas sistem renin angiotensin aldosterone (RAAS) (2).

Harbone menyatakan flavonoid adalah senyawa fenolik. Rzepecka-Stojko menyatakan aktivitas antioksidan senyawa fenolik berhubungan dengan ikatan rangkap dan gugus hidroksil dalam kerangkanya. Dari penelitian Balasuriya dan Guerrero, flavonoid mempunyai aktivitas menginhibisi ACE, aktivitas ini dikarenakan terbentuknya kompleks khelat di pusat aktif ACE, dan bergantung pada fitur struktural utama dari flavonoid.

Oleh karena itu kandungan flavonoid dalam ekstrak dan aktivitas antioksidan yang telah dibuktikan, menunjang kemampuan aktivitas antihipertensi dari ekstrak metanol akar alang-alang dari Kendari.

\section{Kesimpulan}

Dekstrin dari pati kacang merah dapat dihasilkan menggunakan metode enzimatis dan memenuhi persyaratan warna, derajat kehalusan, kadar air, kadar abu dan nilai dekstrosa ekivalen menurut SNI No 01-2593 tahun 1992. Dari skrining flavonoid diperoleh hasil positif, berarti ekstrak megandung flavonoid, penelitian selanjutnya menentukan kadar flavonoid total dan diperoleh hasil 1,17\%. Dengan demikian dapat disimpulkan bahwa ekstrak metanol akar alangalang dari Kendari mengandung flavonoid, dengan kadar total flavonoid 1,17\%.

\section{Daftar Pustaka}

[1] Kementerian Kesehatan. (2013). Riset Kesehatan Dasar. Badan Penelitian Dan Pengembangan Kesehatan Kementerian Kesehatan RI. Halaman vii, 48 dan 89.

[2] Baradaran, A., Nasri, H., dan Kopaei, R. M. (2014). Oxidative Stress and Hypertension: Possibility of Hypertension Therapy with Antioxidants. Journal of Research in Medical Sciences, 19 (4). Halaman 358-367.

[3] Briones, A. M., Touyz, R. M. (2010). Oxidative Stress and Hypertension: Current Concepts. Current Hypertension Reports, 12. Halaman $135-142$.

[4] Upadhyay, S., dan Dixit, M. (2015). Role of Polyphenols and Other Phytochemicals on Molecular Signaling. Oxidative Medicine and Cellular Longevity. Article ID 504253.

[5] Brewer, M. S. (2011). Natural Antioxidants: Sources, Compounds, Mechanisms of Action, and Potential Applications. Comprehensive Reviews in Food Science and Food Safety, 10. Halamam 221-247.

[6] Rzepecka-Stojko, A., Stojko, J., dkk. (2015). Polyphenols from Bee Pollen: Structure, Absorption, Metabolism and Biological Activity. Molecules, 20. Halaman 21732-21749.

[7] Balasuriya, N., dan Rupasinghe, V. H. P. (2011). Plant Flavonoids as Angiotensin Converting Enzyme Inhibitors in Regulation of Hypertension. Functional Foods in Health and Disease, 1 (5). Halaman 172-188.

[8] Guerrero, L., Castillo, J., dkk. (2012). Inhibition of Angiotensin-Converting Enzyme Activity by Flavonoids Structure-Activity Relationship Studies. PLOS One, (11). e49493.

[9] Dhianawaty, D. D. (2016). Kajian Etnofarmakologi Tumbuhan untuk Mengatasi Batu Kandung Kemih (Dari Data Empirik Tradisional Sampai Ke Pembuktian Aktivitas Farmakologi Menuju Uji Klinik). Unpad Press, Jatinangor, Indonesia. Halaman 24-27.

[10] Ruslin, Asmawi, M. Z., dkk. (2013). Anti-hypertensive activity of alang-alang (Imperata cylindrica) (L) Beauv. Root Methanolic Extract on Male Wistar Rat. International Journal of Research in Pharmaceutical Sciences, 4 (4). Halaman 537-542.

[11] Dhianawaty,D, danRuslin.(2015). Polifenol dan Aktivitas Antioksidan dari Ekstrak Metanol Akar Imperata cylindrica (L) Beauv. (Alang-alang). Majalah Kedokteran Bandung, 47 (1). Halaman 60-64.

[12] Harbone, J. B. (1998). Phytochemical Methods. A Guide to Modern Techniques of Plant Analysis, $3^{\text {rd }}$ Edition. Springer PL, New Delhi, India. Halaman 40-66.

[13] Aminah, Tomayahu, N., dan Abidin, Z. (2017). Penetapan Kadar Flavonoid Total Ekstrak Etanol Kulit Buah Alpukat (Persea americana Mill.) dengan Metode Spektrofotometri Uv-Vis. Jurnal Fitofarmaka Indonesia, 4 (2). Halaman 226-230.

[14] Azizah, D. N, Kumolowati, E., dan Faramayuda, F. (2014). Penetapan Kadar Flavonoid Metode Alcl3 Pada Ekstrak Metanol Kulit Buah Kakao (Theobroma cacao L.). Kartika Jurnal Ilmiah Farmasi, 2 (2). Halaman 45-49. 